\title{
Effect Modification by Age and Comorbidities on the Association Between Periodontitis and Female Breast Cancer: A Population-based Case-control Study
}

\section{Chien-Chih Chen}

Taichung Veterans General Hospital https://orcid.org/0000-0001-6508-6448

Wei-Li Ho

Taichung Veterans General Hospital

Ching-Heng Lin

Taichung Veterans General Hospital

Hsin-Hua Chen ( $\square$ shc5555@vghtc.gov.tw)

National Chung-Hsing University https://orcid.org/0000-0002-7304-4587

\section{Research article}

Keywords: breast cancer, periodontitis

Posted Date: March 17th, 2021

DOI: https://doi.org/10.21203/rs.3.rs-310502/v1

License: (c) (i) This work is licensed under a Creative Commons Attribution 4.0 International License.

Read Full License 


\section{Abstract}

Background: The association between periodontitis and female breast cancer is not clear. The purpose of this study is to assess that periodontitis was associated with the risk of female breast cancer.

Methods: Using claims data taken from the 1997-2013 Taiwanese National Health Insurance Research Database (NHIRD), we identified 60,756 newly-diagnosed female breast cancer patients during the period 2003-2013 from all beneficiaries. We then randomly selected 243,024 women without breast cancer matching (1:4) for age and the year of the index date during 1997-2013 from a one million representative population acting as the control group. A conditional logistic regression analysis was used to examine the association between periodontitis and the risk of breast cancer, shown as an odds ratio (OR) with a 95\% confidence interval (Cl) after adjustments for the Charlson Comorbidity Index (CCI), geographic region and level of urbanization.

Results: The mean \pm standard deviation age was $53 \pm 14$ years. After adjusting for potential confounders, the risk of female breast cancer was found to be associated with a history of periodontitis (OR, 1.12; $95 \%$ $\mathrm{Cl}, 1.10-1.14)$. Such an association was significantly different between patients aged $<65$ years $(\mathrm{OR}, 1.09$; $95 \% \mathrm{Cl}, 1.06-1.11)$ and patients aged $\geq 65$ years (OR, 1.23; $95 \% \mathrm{Cl}, 1.18-1.28 ; \mathrm{p}$ for interaction $<0.001)$, as well as between patients where the $\mathrm{CCl}=0(\mathrm{OR}, 1.17 ; 95 \% \mathrm{Cl}, 1.15-1.20)$ and patients with $\mathrm{CCl}>0(\mathrm{OR}$, $0.99 ; 95 \% \mathrm{Cl}, 0.96-1.03 ; \mathrm{p}$ for interaction $<0.001)$. The highest level of urbanization was also associated with the risk of breast cancer.

Conclusions: This nationwide, population-based case-control study demonstrated that periodontitis was significantly associated with the risk of female breast cancer and such an association was modified by both age and comorbidities.

\section{Background}

Female breast cancer is one of the most common malignancies among women worldwide [1]. In Taiwan, the age-standardized incidence rate of female breast cancer per 100,000 persons was 44.5 and significantly increased during 2000-2006 [2], with the mean hospital treatment cost and length of stay also having increased [3]. Prior studies have shown that the age of menarche, pregnancy, breastfeeding, late menopause, obesity, alcohol use and lack of physical activity were risk factors for breast cancer [4, 5], and a recent study has demonstrated that BRCA mutation carriers experience more severe disease and poorer outcomes [6].

Periodontitis is a chronic oral inflammation condition which is altered by microbiota and the microenvironment [7]. Several reports have shown the association between periodontitis and various chronic inflammatory diseases, including coronary heart disease, stroke, pneumonia, chronic obstructive pulmonary disease, chronic kidney disease, and diabetes mellitus [7-10], which may be due to an altered immune cell function [11-13]. Because immune cell function is affected by periodontitis, this response may theoretically correlate with the development of cancer. Certain studies have demonstrated that 
periodontitis has also been revealed as having an association with an increased risk of several cancers, including esophageal cancer, head and neck cancer, as well as lung cancer [14-18].

In Taiwan, the prevalence of periodontitis also significantly increased from $11.5-19.59 \%$ during the period 1997 to 2013 [19]. The available data regarding the association between periodontitis and breast cancer is limited. To the best of our knowledge, only 2 cohort studies $[20,21]$ with small sample sizes have been reported. Soder et al. [20] revealed that severe periodontal disease increased the risk of breast cancer, while Sfreddo et al. [21] found there was a significant association between periodontitis and breast cancer. However, no population-based study with a large sample size has investigated the relationship. The data from the Taiwanese Health Insurance Research Database (NHIRD) is available for nationwide, population-based studies. Therefore, in this study we used data taken from the NHIRD to assess the relationship between periodontitis and female breast cancer.

\section{Materials And Methods}

\section{Ethics statement}

The study was permitted by the Institutional Review Board (IRB) of Taichung Veterans General Hospital (IRB Number: CE17100B).

The requirement for informed consent was waived given that personal information was anonymized.

\section{Study design}

This study was a nationwide, population-based case-control study.

\section{Data source}

The study data included the 1997-2013 administrative data from the NHIRD. The National Health Insurance (NHI) program currently covers over $99 \%$ of the Taiwanese population. The data found within the NHIRD includes medication prescription history, ambulatory care services, admission services and traditional medical services. Certain personal data and history data, such as body weight, body height, alcohol use, and smoking habits, are not available in the NHIRD. The National Health Research Institute (NHRI) manages the NHIRD and provides the database to researchers for research purposes after anonymization of personal information is assured.

We utilized NHIRD datasets to select newly diagnosed female breast cancer patients and matched patients found during the period 2003 to 2013. In 2000, the NHRI randomly selected and enrolled one million representative individuals from the NHIRD, establishing the Longitudinal Health Insurance Database (LHID2000). We selected non-breast cancer comparison cohorts from the population found in the LHID2000. We used LHID2000 claims data from 2003 to 2013 for analysis of the comparison cohorts. 


\section{Identification of female breast cancer patients from the entire Taiwanese population}

Female breast cancer patients were defined as those having a Catastrophic Illness Certificate (CIC) for breast cancer [International Classification of Diseases, Ninth Revision, Clinical Modification (ICD-9-CM) code 174]. Using the NHIRD, we identified 87,738 newly diagnosed female breast cancer patients during the period of 2003-2013.

\section{Selection of matched female breast cancer patients and female non-breast cancer controls}

A total of 60,756 matched patients were included in the female patient group during the period of 20032013. Patients who matched index date and age without the diagnosis of female breast cancer (ICD-9-CM code 174) were included in the non-breast cancer female group. There were 421,288 non-breast cancer females included in this dataset from 2003 to 2013. The ratio of female breast cancer patients and nonbreast cancer females was 1:4, with a total of 243,024 patients enrolled in the matched non-breast cancer group during the period of 2003-2013.

\section{Definition of periodontitis}

Patients with a diagnosis of periodontitis were defined as having ICD-9 code 523.3-523.5. We used the cumulative number of visits for periodontitis treatment and the cumulative cost of periodontitis related visits as proxies for the severity of periodontitis.

\section{Potential confounders}

Potential confounders included level of urbanization and $\mathrm{CCl}$. The $\mathrm{CCl}$, as adapted by Deyo et al. (22), was used to represent the general level of comorbidity medical conditions. The presence of comorbidity was defined as a patient having at least three ambulatory visits or one inpatient visit with a corresponding ICD-9-CM code within 1 year prior to the index date. Sensitivity analyses were conducted based upon age ( $<65$ years, $\geq 65$ years) and $\mathrm{CCl}$.

\section{Dose-response relationship}

In order to measure the relationship between the severity of periodontitis and breast cancer, the period between the last periodontitis visit date to breast cancer diagnosis date (ie, 0-3 months, 3- 6 months, 6 months-1 year, 1-3 years, > 3 years), the number of visits required for acute or chronic periodontitis according to the 25th, 50th and 75th centiles, and the cumulative cost of acute or chronic periodontitisrelated visits according to the 25th, 50th and 75th centiles were incorporated into the analysis.

\section{Statistical analysis}

We tested the differences in the continuous variables through use of the Student's $t$-test and the categorical variables by using the Pearson's $\chi^{2}$ test. A conditional logistic regression analysis was used to examine the association between periodontitis exposure and the risk of breast cancer development after 
adjustment for potential confounders. This analysis involved the Charlson Comorbidity Index (CCl), geographical region (i.e., northern, southern, western and eastern) and the level of urbanization (i.e., Leve1 1 to 4) (23). These statistical analyses were performed using SAS statistical software, version 9.3 (SAS Institute, Inc., Cary, NC, USA). A p value less than 0.05 was considered statistically significant.

\section{Results}

Table 1 demonstrates the demographic data of the matched female breast cancer patients and the nonbreast cancer female controls. The mean \pm SD age was 53 years in both groups. Female breast cancer patients had a higher proportion of having a history of periodontitis than the control group. Most female breast cancer patients lived in the northern region, while there was a higher incidence of breast cancer in the more urbanized regions. 
Table 1

Demographic data of patients with breast cancer and non-breast cancer controls

\begin{tabular}{|c|c|c|c|}
\hline & $\begin{array}{l}\text { Female Non- Breast } \\
\text { Cancer patients }\end{array}$ & $\begin{array}{l}\text { Female Brest Cancer } \\
\text { patients }\end{array}$ & \\
\hline & $(n=243,024)$ & $(n=60,756)$ & $\begin{array}{l}P \text { - } \\
\text { value }\end{array}$ \\
\hline Age, years (mean $\pm S D)$ & $53 \pm 14$ & $53 \pm 14$ & 1 \\
\hline $\begin{array}{l}\text { Gingival and periodontal diseases } \\
\text { (ICD9-CM: 523) }\end{array}$ & $106,081(43.7)$ & $28,358(46.7)$ & $\begin{array}{l}< \\
0.001\end{array}$ \\
\hline $\begin{array}{l}\text { Acute or chronic periodontitis (ICD9- } \\
\text { CM: } 523.3-4 \text { ) }\end{array}$ & $69,604(28.6)$ & $19,018(31.3)$ & $\begin{array}{l}< \\
0.001\end{array}$ \\
\hline $\begin{array}{l}\text { Chronic periodontitis (ICD9-CM: } \\
\text { 523.4) }\end{array}$ & $18,917(7.8)$ & $5,343(8.8)$ & $<.001$ \\
\hline Periodontitis (ICD9-CM: 523.3-5) & $94,477(38.9)$ & 25,357 (41.7) & $\begin{array}{l}< \\
0.001\end{array}$ \\
\hline Geographic region & & & $<.001$ \\
\hline Northern & $124,252(51.1)$ & $33,455(55.1)$ & \\
\hline Central & $44,956(18.5)$ & $10,593(17.4)$ & \\
\hline Southern & $69,775(28.7)$ & $15,792(26.0)$ & \\
\hline Eastern & $4,041(1.7)$ & $916(1.5)$ & \\
\hline Level of urbanization & & & $\begin{array}{l}< \\
0.001\end{array}$ \\
\hline 0 most urbanization & $81,755(33.6)$ & 23,091 (38.0) & \\
\hline 1 & $108,933(44.8)$ & $26,900(44.3)$ & \\
\hline 2 & $35,724(14.7)$ & $7,680(12.6)$ & \\
\hline 3 least urbanization & $16,612(6.8)$ & $3,085(5.1)$ & \\
\hline
\end{tabular}


Table 2

Comparison of previous existing periodontitis severity factors before index date between patients with breast cancer and non-breast cancer controls

\begin{tabular}{|c|c|c|c|}
\hline & $\begin{array}{l}\text { Female Non- Breast } \\
\text { Cancer patients }\end{array}$ & $\begin{array}{l}\text { Female Brest } \\
\text { Cancer patients }\end{array}$ & \\
\hline & $(n=243,024)$ & $(n=60,756)$ & $\begin{array}{l}P \text { - } \\
\text { value }\end{array}$ \\
\hline $\begin{array}{l}\text { Last periodontitis visit date to breast cancer } \\
\text { diagnosis date }\end{array}$ & & & $<.001$ \\
\hline $0-3$ months & 4,065 (1.7) & $1,466(2.4)$ & \\
\hline $3-6$ months & $4,080(1.7)$ & $1,201(2.0)$ & \\
\hline 6 months -1 year & 7,023 (2.9) & $1,884(3.1)$ & \\
\hline $1-3$ years & $19,505(8.0)$ & $5,162(8.5)$ & \\
\hline$>3$ years & $34,931(14.4)$ & $9,305(15.3)$ & \\
\hline $\begin{array}{l}\text { Number of visits for Acute or chronic } \\
\text { periodontitis }\end{array}$ & & & $\begin{array}{l}< \\
0.001\end{array}$ \\
\hline Q1Q2(1) & $51,369(21.1)$ & $13,917(22.9)$ & \\
\hline Q3(2) & $10,824(4.5)$ & 2,985 (4.9) & \\
\hline $\mathrm{Q} 4(>2)$ & 7,411 (3.0) & 2,116 (3.5) & \\
\hline $\begin{array}{l}\text { Cumulative cost of Acute or chronic } \\
\text { periodontitis-related visits (US\$) }\end{array}$ & & & $<.001$ \\
\hline Q1(13) & $17,902(7.4)$ & 4,662 (7.7) & \\
\hline Q2(16) & $18,314(7.5)$ & 5,269 (8.7) & \\
\hline Q3(43) & $16,964(7.0)$ & 4,454 (7.3) & \\
\hline Q4(> 43) & $16,424(6.8)$ & 4,633 (7.6) & \\
\hline \multicolumn{4}{|l|}{ Comorbidity } \\
\hline $\mathrm{CCl}$ group & $0.4 \pm 1.0$ & $1.2 \pm 2.3$ & $<.001$ \\
\hline 0 & $196,320(80.8)$ & 41,007 (67.5) & $<.001$ \\
\hline$\geq 1$ & 46,704 (19.2) & 19,749 (32.5) & \\
\hline
\end{tabular}


Table 3

Adjusted odds ratio with $95 \%$ confidence interval for the periodontitis

\begin{tabular}{|lllll|}
\hline & OR $(95 \% \mathrm{Cl})$ & $\begin{array}{l}\text { P- } \\
\text { value }\end{array}$ & $\begin{array}{l}\text { Adjusted OR (95\% } \\
\text { Cl) }\end{array}$ & $\begin{array}{l}\text { P- } \\
\text { value }\end{array}$ \\
\hline $\begin{array}{l}\text { Gingival and periodontal diseases (ICD9- } \\
\text { CM: 523) }\end{array}$ & $\begin{array}{l}1.14(1.12- \\
1.16)\end{array}$ & $\begin{array}{l}< \\
0.001\end{array}$ & $1.11(1.09-1.13)$ & $<$ \\
Acute or chronic periodontitis & $1.14(1.12-$ & $<$ & $1.12(1.10-1.14)$ & $<$ \\
(ICD9-CM: 523.3-4) & $1.17)$ & 0.001 & 0.001 \\
\hline Chronic periodontitis (ICD9-CM: 523.4) & $1.15(1.11-$ & $<$ & $1.11(1.07-1.15)$ & $<$ \\
& $1.18)$ & 0.001 & & 0.001 \\
\hline Periodontitis & $1.13(1.11-$ & $<$ & $1.10(1.08-1.12)$ & $<$ \\
(ICD9-CM: 523.3-5) & $1.16)$ & 0.001 & & 0.001 \\
\hline Adjust for patient, CCl, geographic region, and Urban & & & \\
\hline
\end{tabular}

Table 2 compares the previously existing periodontitis severity factors prior to the index date between the patients with breast cancer and the non-breast cancer controls. After having matched the index date and ages, the period between the last periodontitis visit date to the breast cancer diagnosis date was shorter in the female breast cancer patients than in the matched non-breast cancer females $(p<0.001)$. The number of visits for periodontitis treatment were more for the female breast cancer patients than in the matched non-breast cancer females $(p<0.001)$. Additionally, the cumulative cost of periodontitis related visits was higher in the female breast cancer patients than in the matched non-breast cancer females $(p<$ 0.001 ). And finally, the female breast cancer patients had more comorbidities than the matched nonbreast cancer females $(p<0.001)$.

As shown in Table 3, the association between periodontitis and breast cancer was consistent using various definitions of periodontitis, implying that acute and/or chronic periodontitis was associated with breast cancer.

Table 4 shows the adjusted odds ratio (OR) of breast cancer. After adjusting for age and index date, the risk of female breast cancer was associated with a history of periodontitis $(\mathrm{OR}, 1.12 ; 95 \% \mathrm{Cl}, 1.10-1.14]$. A short interval period between the last periodontitis visit date to the breast cancer diagnosis date (OR, $1.46 ; 95 \% \mathrm{Cl}, 1.37-1.55)$, more periodontitis visits (OR, $1.17 ; 95 \% \mathrm{Cl}, 1.11-1.23)$, a higher cumulated periodontitis-related cost $(\mathrm{OR}, 1.15 ; 95 \% \mathrm{Cl}, 1.11-1.19)$, and higher urbanization level were all associated with the risk of breast cancer. 
Table 4

Crude and Adjusted odds ratio with 95\% confidence interval for the association between the variables and periodontitis

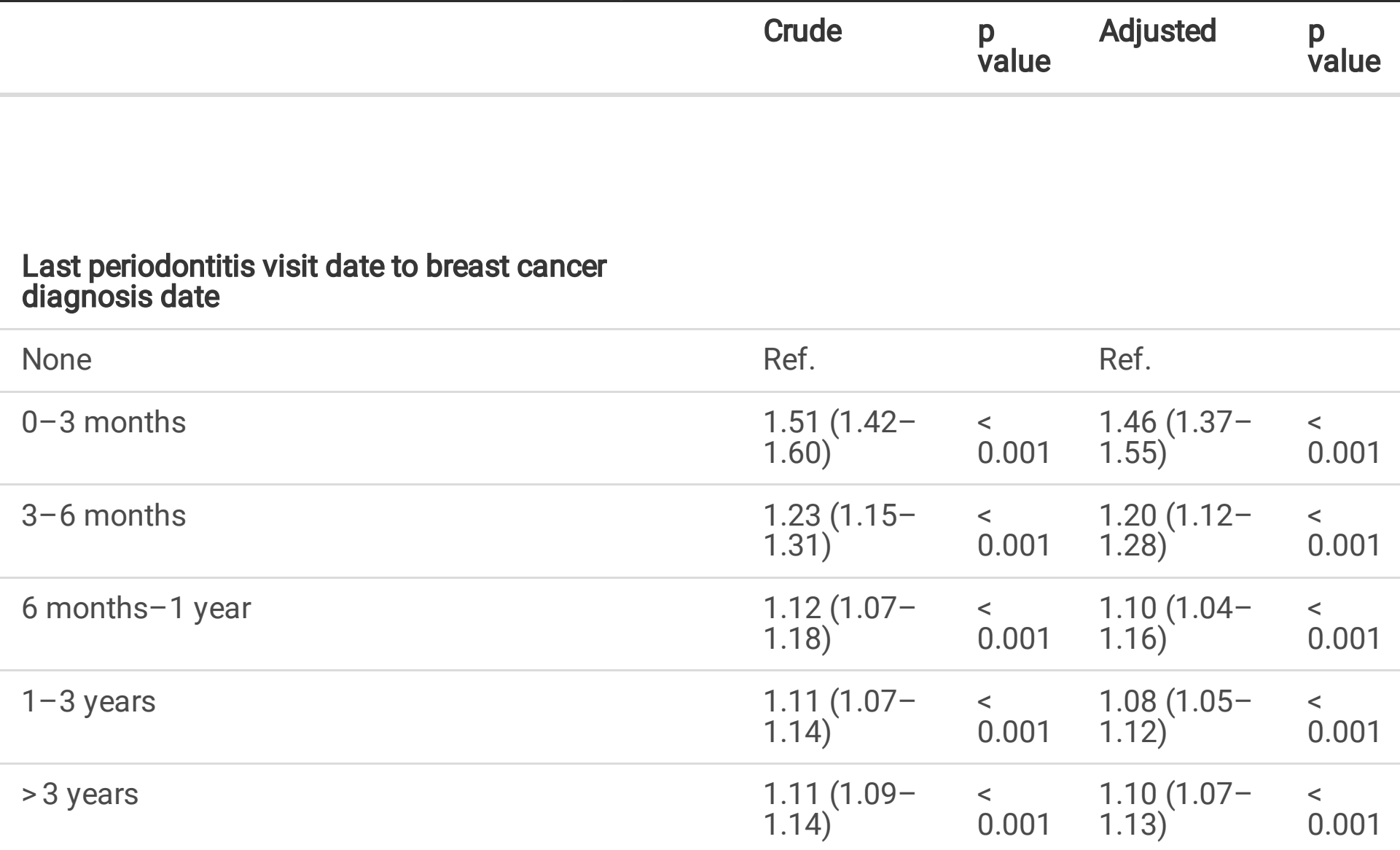

Number of visits for Acute or chronic periodontitis

None

Ref.

Ref.

Q1Q2(1)

$1.13(1.11-$

1.16)

$<$

0.001

$1.11(1.09-<$

Q3(2)

$1.15(1.11-$

$<$

1.14)

0.001

Q3(2)

1.20)

0.001

$1.12(1.07-<$

Q4(>2)

$1.20(1.14-$ 0.001

$1.17(1.11-$

0.001

1.26)

$0.001 \quad 1.23)$

0.001

\section{Cumulative cost of Acute or chronic periodontitis-}

related visits (US\$)

None

Q1(13)

Q2(16)
Ref.

$1.09(1.05-$

1.12)

$1.21(1.17-$

1.25)
Ref.

$1.08(1.04-<$

1.11

0.001

$1.19(1.15-<$

1.23) 


\begin{tabular}{|c|c|c|c|c|}
\hline & Crude & $\begin{array}{l}p \\
\text { value }\end{array}$ & Adjusted & $\begin{array}{l}\mathrm{p} \\
\text { value }\end{array}$ \\
\hline Q3(43) & $\begin{array}{l}1.10(1.06- \\
1.14)\end{array}$ & $<0.001$ & $\begin{array}{l}1.06(1.03- \\
1.10)\end{array}$ & $\begin{array}{l}< \\
0.001\end{array}$ \\
\hline Q4(> 43) & $\begin{array}{l}1.18(1.14- \\
1.22)\end{array}$ & $\begin{array}{l}< \\
0.001\end{array}$ & $\begin{array}{l}1.15(1.11- \\
1.19)\end{array}$ & $<0.001$ \\
\hline \multicolumn{5}{|l|}{$\mathrm{CCl}$ group } \\
\hline 0 & Ref. & & Ref. & \\
\hline$\geq 1$ & $\begin{array}{l}2.31(2.26- \\
2.36)\end{array}$ & $\begin{array}{l}< \\
0.001\end{array}$ & $\begin{array}{l}2.32(2.27- \\
2.38)\end{array}$ & $<0.001$ \\
\hline \multicolumn{5}{|l|}{ Level of urbanization } \\
\hline 0 most urbanization & Ref. & & Ref. & \\
\hline 1 & $\begin{array}{l}0.87(0.86- \\
0.89)\end{array}$ & $\begin{array}{l}<.001 \\
0.01\end{array}$ & $\begin{array}{l}0.89(0.87- \\
0.91)\end{array}$ & $\begin{array}{l}<.001 \\
0.001\end{array}$ \\
\hline 2 & $\begin{array}{l}0.76(0.74- \\
0.78)\end{array}$ & $\begin{array}{l}<.001 \\
0.00\end{array}$ & $\begin{array}{l}0.78(0.75- \\
0.80)\end{array}$ & $<0.001$ \\
\hline 3 least urbanization & $\begin{array}{l}0.65(0.63- \\
0.68)\end{array}$ & $<0.001$ & $\begin{array}{l}0.68(0.65- \\
0.71)\end{array}$ & $\begin{array}{l}< \\
0.001\end{array}$ \\
\hline
\end{tabular}

Adjust for $\mathrm{CCl}$ and level of urbanization and index year

Table 5 shows that the association was significantly different between patients $<65$ years of age (OR, $1.09 ; 95 \% \mathrm{Cl}, 1.06-1.11)$ and patients $\geq 65$ years of age $(\mathrm{OR}, 1.23 ; 95 \% \mathrm{Cl}, 1.18-1.28 ; \mathrm{p}$ for interaction < $0.001)$, as well as between patients without the $\mathrm{CCl}(\mathrm{OR}, 1.17 ; 95 \% \mathrm{Cl}, 1.15-1.20)$ and patients with the $\mathrm{CCl}(\mathrm{OR}, 0.99 ; 95 \% \mathrm{Cl}, 0.96-1.03 ; \mathrm{p}$ for interaction < 0.001).

Table 5

stratified analyses on the basis of age and $\mathrm{CCl}$ group

\begin{tabular}{|llll|}
\hline & OR $(95 \% \mathrm{Cl})$ & P-value & Effect modification P value \\
\hline Age & & $<0.001$ \\
\hline Age $<65$ & $1.09(1.06-1.11)$ & $<0.001$ & \\
\hline Age $\geq 65$ & $1.23(1.18-1.28)$ & $<0.001$ & \\
\hline CCl group & & & $<0.001$ \\
\hline 0 & $1.17(1.15-1.20)$ & $<0.001$ & \\
\hline 1 & $0.99(0.96-1.03)$ & 0.726 & \\
\hline Adjust for patient's Age, Comorbidity, Urban & \\
\hline
\end{tabular}




\section{Discussion}

This is the first nationwide, population-based case control study which assesses the association between a history of periodontitis and the risk of breast cancer development in Asia, and we have demonstrated that breast cancer risk increased in periodontitis patients. Soder et al. [20] selected 3,273 patients aged between 30-40 years and found that chronic periodontitis indicated by missing molars seemed to be associated with breast cancer. Sfreddo et al. [21] selected 67 breast cancer patients and 134 controls and found a significant association between periodontitis and breast cancer. Freudenheim et al. [24] analyzed the cohort of 73,737 postmenopausal women and revealed that periodontitis increased the risk of postmenopausal breast cancer. We enrolled 60,756 breast cancer patients and 243,024 matched female non-breast cancer patients in this study and found that there was a strong correlation between periodontitis and breast cancer.

The shorter the interval period between the last periodontitis visit date to the breast cancer diagnosis date, the more number of visits for periodontitis, and the higher cumulative cost of periodontitis related visits implied that there was more active and severe periodontitis. Additionally, we discovered that there was a higher risk of breast cancer in the patients who had more active and severe periodontitis. Soder et al. [20] defined missing molars as severe periodontitis, with severe periodontitis increasing the risk of breast cancer.

Another important finding was that the association between periodontitis and female breast cancer was significantly different on the basis of age and $\mathrm{CCl}$. In subgroup analysis, elderly patients 65 years or older had a higher risk of breast cancer than younger patients. The reason for this may be that elderly patients may have had a longer history of periodontitis, along with greater exposure to bacteria and chronic inflammation over a longer period of time. Periodontitis effects decreased in patients who had multiple comorbidity diseases. Other diseases or comorbidities had different mechanisms which affected breast cancer. Cao et al. [25] revealed that overall survival and progression-free survival of breast cancer were impacted by age and $\mathrm{CCl}$, implying that age and $\mathrm{CCl}$ play an important role in breast cancer. In this study, one important finding is that the risk of breast cancer is modified by both age and comorbidities.

Periodontitis had more effect on female breast cancer, particularly for patients without any comorbidities and older than 65 years of age. Closer follow up of these higher risk patients may be helpful in future cancer surveillance studies.

The mechanism of periodontitis induced breast cancer still remain unclear.

Oral cavity bacteria may play a role in the potential mechanism.

Previous studies [26-28] have found that breast duct tissue was exposed to various bacteria, with bacteria also being found in breast tumors. The long-term bacteria stimulation and inflammation seems to lead to cancer formation. Periodontitis is a chronic inflammation condition and its associated systemic inflammation status may play a role as another mechanism. Certain studies [29-33] have revealed that periodontal disease increased systemic inflammation markers, including C-reactive protein (CRP), cytokines and chemokines. Chan et al. [29] reviewed the meta-analysis of several studies and found that 
circulating CRT, a low grade inflammation marker, was associated breast cancer development. Noack et al. [31] showed CRP levels increased in periodontitis patients. Hayashi et al. [32] demonstrated oral pathogens can induce and maintain a chronic state of inflammation at sites distant from oral infection. Elinav et al. [33] showed that microbials played an important role in inflammation induced cancer, and also affected cancer development. These inflammation markers had an impact on carcinogenesis and could explain the association between periodontitis and breast cancer.

Some limitations were noted in this study. First, some confounders, including menarche, pregnancy, breastfeeding, menopause, body weight, body height, alcohol use, and smoking, were not made available in this study, and all these factors can affect the risk of breast cancer. Second, the severity of periodontitis may affect one's inflammation status, which could lead to breast cancer. In order to overcome these limitations, we enrolled large numbers of matched patients and stratified patients by their number of visits for periodontitis treatment and the cumulative cost of their periodontitis related visits. A higher number of visits for periodontitis treatment, along with a higher cumulative cost for periodontitis related visits, resulted in patients being considered as having more active and severe periodontitis.

\section{Conclusion}

Periodontitis is significantly associated with breast cancer and the effect of periodontitis is modified by both age and comorbidities.

\section{Abbreviations}

NHIRD

National Health Insurance Research Database

OR

odds ratio.

$\mathrm{Cl}$

confidence interval.

$\mathrm{CCl}$

Charlson Comorbidity Index.

IRB

Institutional Review Board.

$\mathrm{NHI}$

National Health Insurance.

$\mathrm{NHRI}$

National Health Research Institute.

LHID2000

Longitudinal Health Insurance Database.

$\mathrm{CIC}$

Catastrophic Illness Certificate. 
ICD-9-CM

International Classification of Diseases, Clinical Modification.

\section{Declarations}

\section{Acknowledgements}

This study was supported by Taichung Veterans General Hospital.

\section{Conflict of interests}

The authors declare that there are no conflicts of interest.

\section{DATA AVAILABILITY STATEMENT}

All datasets generated for this study are included in the article.

\section{ETHICS STATEMENT}

The study reviewed and approved by Ethics Committee in Taichung Veterans General hospital.

\section{AUTHOR CONTRIBUTIONS}

CCC writing original draft and acquisition of data.

WLH contributed to the data collection and advised the analysis.

$\mathrm{CHL}$ contributed to the data collection and advised the manuscript.

HHC data analysis and interpretation, and revising article and study supervision.

\section{FUNDING}

This study was supported by grants from Taichung Veterans General hospital.

\section{Consent for publication}

Not applicable.

\section{References}

1. Ferlay J, Soerjomataram I, Dikshit R, Eser S, Mathers C, Rebelo M, et al. Cancer incidence and mortality worldwide: sources, methods and major patterns in GLOBOCAN 2012. Int J Cancer. 2015;136:E359-86. doi:10.1002/ijc.29210.

2. Chen BK, Yang CY. Temporal trend analysis of avoidable mortality in Taiwan, 1971-2008: overall progress, with areas for further medical or public health investment. BMC Public Health. 2013;13:551. 
doi:10.1186/1471-2458-13-551.

3. Chang HT, Shi HY, Wang BW, et al. Breast cancer incidence and predictors of surgical outcomes: a nationalwide longitudinal study in Taiwan. Clin Oncol. 2017;29:362-9.

doi:10.1016/j.clon.2017.01.005.

4. Howell A, Anderson AS, Clarke RB, Duffy SW, Evans DG, Garcia-Closas M, et al. Risk determination and prevention of breast cancer. Breast Cancer Res. 2014;16:446. doi:10.1186/s13058-014-0446-2.

5. Colditz GA, Bohlke K. Priorities for the primary prevention of breast cancer. CA Cancer J Clin. 2014;64:186-94. doi.org/10.3322/caac.21225.

6. Wang YA, Jian JW, Hung CF, et al. Germline breast cancer susceptibility gene mutations and breast cancer outcomes. BMC Cancer. 2018;18:315. doi:10.1186/s12885-018-4229-5.

7. Linden GJ, Herzherg MC, on behalf of working group 4 of the joint EFP/AAP workshop. Periodontitis and systemic diseases: a record of discussions of working group 4 of the Joint EFP/AAP Workshop on Periodontitis and Systemic Diseases. J Periodontol. 2013;84:20-3. doi:10.1902/jop.2013.1340020.

8. Humphrey LL, Fu R, Buckley DI, Freeman M, Helfand M. Periodontal disease and coronary heart disease incidence: A systematic review and mera-analysis. J Gen Intern Med. 2008;23:2079-86. doi:10.1007/s11606-008-0787-6.

9. Janket SJ, Baird AE, Chuang SK, Jones JA. Meta-analysis of periodontal diease and risk of coronary heart disease and stroke. Oral Surg Oral Med Oral Pathol Oral Radiol Endod. 2003;95:559-69. doi:10.1067/moe.2003.107.

10. Gurav A, Jadhav V. Periodontitis and risk of diabetes mellitus. J Diabetes. 2011;3:21-8. doi:10.1111/j.1753-0407.2010.00098.x.

11. Festa A, D'Agostino RDJ, Howard G, et al. Chronic subclinical inflammation as apart of the insulin resistance syndrome. The insulin resistance atherosclerosis study (IRAS). Circulation. 2000;102:427.

12. Salvi GE, Collins JG, Yalda B, et al. Monocytic TNF-a secretion patterns in IDDM patients with periodontal diseases. J Clin Periodontol. 1997;24:8-16.

13. Naguib G, Al-Mashat H, Desta T, Graves D. Diabetes prolongs the inflammatory response to a bacterial stimulus through cytokine dysregulation. J Invest Dermatol. 2004;123:87-92.

14. Fitzpatrick SG, Katz J. The association between periodontal disease and cancer: A review of the literature. J Dentistry. 2010;38:83-95. doi:10.1016/j.jdent.2009.10.007.

15. Ahn J, Segers S, Hayes RB. Periodontal diseae, Porphyromonas gingivalis serum antibody levels and orodigestive cancer mortality. Carcinogenesis. 2012;33:1055-8. doi:10.1093/carcin/bgs112.

16. Linden GJ, Lyons A, Scannapieco FA. Periodontal systemic associations: review of the evidence. J Clin Periodontol. 2013;84:8-19. doi:10.1111/jcpe.12064.

17. Michaud DS, Izard J, Wilhelm-Benartzi CS, You DH, Grote VA, Tjonneland A, et al. Plasma antibodies to oral bacteria and risk of pancreatic cancer in a large European prospective cohort study. Gut. 
2013;62:1764-70. doi:10.1136/gutjnl-2012-303006.

18. Tezal M, Sullivan MA, Hyland A, Marshall JR, Stoler D, Reid ME, et al. Chronic periodontitis and the incidence of head and neck squamous cell carcinoma. Ca Epidemiol Biomarkers Prev. 2009;18:2406-2012. doi:10.1158/1055-9965.

19. Yu HC, Su NY, Huang JY, et al. Trends in the prevalence of periodontitis in Taiwan from 1997 to 2013: A nationwide population-based retrospective study. Medicine. 2017;96:e8585. doi:10.1097/MD.0000000000008585.

20. Soder B, Yakob M, Meruman JH, Andersson LC, Klinge B, Soder PO. Periodontal disease may associate with breast cancer. Breast Cancer Res Treat. 2011;127:497-502. doi:10.1007/s10549-0101221-4.

21. Sfreddo CS, Maier J, De David SC, Susin C, Moreira CHC. Periodontitis and breast cancer: A casecontrol study. Community Dent Oral Epidemiol. 2017;45:545-51. doi:10.1111/cdoe.12318.

22. Deyo RA, Cherkin DC, Ciol MA. Adapting a clinical comorbidity index for use with ICD-9-CM administrative databases. J clin epidemiol. 1992;45:613-9. doi:10.1016/0895-4356(92)90133-8.

23. Liu CY, Hung YT, Chung YL, Chen YJ, Weng WS, Liu JS, et al. Incorporating development stratification of Taiwan townships into sampling design of large scale health interview survey. $J$ Health Manage. 2006;4:1-22. doi:10.29805/JHM.200606.0001.

24. Freudenheim JL, Genco RJ, LaMonte MJ, Millen AE, Hovey KM, Mai X, et al. Periodontal disease and breast cancer: Prospective cohort study of postmenopausal women. Cancer Epidemiol Biomarkers Prev. 2016;25:43-50. doi:10.1158/1055-9965.EPI-15-0750.

25. Cao KI, Salviat F, Laki F, Falcou MC, Carton M, Poortmans P, et al. Outcomes of postoperative radiation therapy for breast cancer in older women according to age and comorbidity status: An observational retrospective study in 752 patients. J Geriatr Oncol. 2018;9:600-5. doi:10.1016/j.jgo.2018.02.008.

26. Urbaniak C, Burton JP, Reid G. Breast, milk and microbes: a complex relationship that does not end with lactation. Womens Health. 2012;8:385-98. doi:10.2217/whe.12.23.

27. Urbaniak C, Cummins J, Brackstone M, Macklaim JM, Gloor GB, Baban CK, et al. Microbiota of human breast tissue. Appl Environ Microbiol. 2014;80:3007-14. doi:10.1128/AEM.00242-14.

28. Xuan C, Shamonki JM, Chung A, Dinome ML, Chung M, Sieling PA, et al. Microbial dysbiosis is associated with human breast cancer. PloS One. 2014;9:e83744. doi:10.1371/journal.pone.0083744.

29. Chan DS, Bandera EV, Greenwood DC, Norat T. Circulating c-reactive protein and breast cancer risksystemic literature review and mera-analysis of prospective cohort studies. Ca Epidemiol Biomarkers Prev. 2015;24:1439-49. doi:10.1158/1055-9965.EPI-15-0324.

30. Joshipura KJ, Wand HC, Merchant AT, Rimm EB. Periodontal disease and biomarkers related to cardiovascular disease. J Dent Res. 2004;83:151-5. doi:10.1177/154405910408300213.

31. Noack B, Genco RJ, Trevisan M, Grossi S, Zambon JJ, De Nardin E. Periodontal infections contribute to elevated systemic C-reactive proterin level. J Periodontol. 2001;72:1221-7. doi:10.1902/jop.2000.72.9.1221. 
32. Hayashi C, Gudino CV, Gibson FC, Genco CA. Pathogen-induced inflammation at sites distant from oral infection: bacteria persistence and induction of cell-specific innate immune inflammatory pathways. Mol Oral Microbiol. 2010;25:305-16. doi:10.1111/j.2041-1014.2010.00582.x.

33. Elinav E, Nowarski R, Thaiss CA, Hu B, Jin C, Flavell RA. Inflammation-induced cancer: crosstalk between tumors, immune cells and microorganisms. Nat Rev Cancer. 2013;13:759-71. doi:10.1038/nrc3611. 